
\title{
An rhl-like quorum-sensing system negatively
regulates pyoluteorin production in Pseudomonas
sp. M18 \\ Correspondence \\ Yuquan $\mathrm{Xu}$ \\ xuyq@sjtu.edu.cn \\ Received 12 June 2006 \\ Revised 19 September 2006 \\ Accepted 10 October 2006

\author{
An Yan, Xianqing Huang, Haiming Liu, Dexian Dong, Dabing Zhang, \\ Xuehong Zhang and Yuquan $\mathrm{Xu}$
} \\ Key Laboratory of Microbial Metabolism, Ministry of Education, College of Life Sciences and Biotechnology, Shanghai Jiao Tong University, 800 Dongchuan Road, Shanghai 200240, P. R. China
}

\section{INTRODUCTION}

Antibiotics produced by the root-associated strains of fluorescent pseudomonads can protect plants against a range of soil-borne phytopathogens (Dowling \& O'Gara, 1994; Thomashow \& Weller, 1996). Various pseudomonad strains used in bio-control synthesize a battery of antibiotics, including polyketides and phenazines, as well as others (Bender et al., 1999; Turner \& Messenger, 1986). The biosynthesis and secretion of these antibiotics occur mostly after the cell has entered into the stationary phase of growth, when bacterial densities have reached a certain threshold; this threshold is detected by a process called quorum sensing (QS) (Fuqua et al., 2001; Withers et al., 2001). QS regulates gene expression via signalling molecules, such as $\mathrm{N}$-acylhomoserine lactones (AHLs), in Gram-negative bacteria (Taga \& Bassler, 2003; Waters \& Bassler, 2005). The concentration of AHL increases along with the increasing bacterial cell density. When the concentration of AHL reaches a threshold level, it binds to specific transcriptional regulators belonging to the LuxR family, and forms various activated protein-AHL complexes. These complexes regulate the transcription of specific target genes, including

Abbreviations: $\mathrm{AHL}, \mathrm{N}$-acylhomoserine lactone; $\mathrm{BHL}, \mathrm{N}$-butyrylhomoserine lactone; $\mathrm{C}_{\mathrm{T}}$, threshold cycle; $\mathrm{HHL}, \mathrm{N}$-hexanoylhomoserine lactone; PCA, phenazine-1-carboxylic acid; Plt, pyoluteorin; OS, quorum sensing.

The GenBank/EMBL/DDBJ accession number for the nucleotide sequence of the rhll gene and the partial sequence of the rh/R gene of Pseudomonas sp. M18 is D0345445. various antibiotic biosynthesis gene clusters in Pseudomonas spp. (Haas \& Keel, 2003).

The QS system, and its function in the regulation of antibiotic production, have been thoroughly investigated in some phenazine-producing strains, particularly Pseudomonas aeruginosa PAO1. There are at least two QS systems in $P$. aeruginosa PAO1, and these are called the las (LasI-LasR) and rhl (RhlI-RhlR) systems (Gambello \& Iglewski, 1991; Ochsner et al., 1994). The major AHLs synthesized by LasI and RhlI are $\mathrm{N}$-(3-oxododecanoyl)homoserine lactone and $N$-butyrylhomoserine lactone (BHL), respectively (Pearson et al., 1994, 1995). Furthermore, these two QS systems do not function independently, but rather arrange in a cascade to positively control the expression of biosynthetic genes for phenazine production (Brint \& Ohman, 1995; Pesci et al., 1997; Schuster et al., 2003). In three other phenazine-producing Pseudomonas strains, i.e. P. aureofaciens 30-84, P. fluorescens 2-79 and P. chlororaphis PCL1391, a conserved system called the PhzI-PhzR QS system has been found to positively regulate phenazine production (Chin-AWoeng et al., 2001; Khan et al., 2005; Wood et al., 1997). In addition, biosynthesis of certain polyketide antibiotics depends on the QS system; for example, the biosynthesis of mupirocin (pseudomonic acid) requires the MupI-MupR QS system in P. fluorescens NCIMB 10586 (El-Sayed et al., 2001).

Pyoluteorin (Plt) is a polyketide compound that can effectively suppress several oomycete fungi including the 
seed- and root-rotting pathogen Pythium ultimum (Bailey et al., 1973; Howell \& Stipanovic, 1980; Maurhofer et al., 1992). Plt is produced by several strains of Pseudomonas spp., including the soil-borne bacteria $P$. fluorescens $\mathrm{Pf}-5$ and CHA0, and the regulation of Plt biosynthesis has been investigated in both of these strains. Studies have revealed that the regulatory circuit controlling Plt production includes positive autoregulation, with Plt acting as a signalling molecule (Brodhagen et al., 2004). The extracellular concentration of Plt increases in parallel with cell density, and accumulates to detectable levels until the cells begin to enter the stationary phase (Brodhagen et al., 2004). In addition, PltR, the LysR-type transcriptional activator, has been presumed to be a candidate receptor (Brodhagen et al., 2004). These properties are very similar to those of AHLs; however, AHLs have not yet been found in pseudomonad strains such as $P$. fluorescens $\mathrm{Pf}-5$ and CHA0, which are known to produce Plt and PltR. Except for these preliminary results that suggest the presence of AHLs, little is known about the relationship between the QS system and Plt production.

The Pseudomonas sp. strain M18 adopted in this study is an effective bio-control agent against soil-borne phytopathogens (Hu et al., 2005). This capability is primarily due to its ability to produce two antibiotics: phenazine-1-carboxylic acid (PCA) and Plt. To the best of the authors' knowledge, this pseudomonad is the first strain that has been reported to produce these two different types of antibiotics together in a single cell (Ge et al., 2004; Hu et al., 2005). In previous work, we described how Plt is positively regulated, and PCA is negatively regulated, by a global regulator called GacA (Ge et al., 2004); however, the reverse relationship occurs in Pseudomonas sp. M18 through another global regulator, RsmA (Zhang et al., 2005). We have also identified a novel pathway-specific regulator of PltZ that could specifically repress Plt biosynthesis (Huang et al., 2004). In a more recent study, we characterized a putative Plt-induced $A B C$ transporter cassette required for Plt production in Pseudomonas sp. M18 (Huang et al., 2006); however, no research has yet been done on the regulation of Plt production by potential AHL signalling molecules secreted by this strain.

This study was initiated using a red-pigment-negative transposon mutant M18-T510, which was derived from Pseudomonas sp. M18. We then identified an rhl QS system, and, to the best of our knowledge, this is the first report indicating that this system can regulate Plt production in Pseudomonas sp. M18. We further demonstrate that Plt production is negatively controlled by this $r h l$ QS system at the transcriptional level, and that this regulation is partially mediated by PltR. In addition, we present evidence that expression of a Plt-specific $\mathrm{ABC}$ transporter is also negatively regulated by the $r h l \mathrm{QS}$ system in a Plt-dependent manner. Finally, we demonstrate that cell growth and red pigment production are also under the control of the rhl QS system.

\section{METHODS}

Bacterial strains and growth conditions. Pseudomonas sp. M18 is a fluorescent Pseudomonas strain isolated from the watermelon rhizosphere, and is an unusual strain sharing some distinct features of both $P$. aeruginosa and $P$. fluorescens (Hu et al., 2005). The other bacterial strains and plasmids used in this study are listed in Table 1. Escherichia coli was routinely grown at $37^{\circ} \mathrm{C}$ in LuriaBertani (LB) medium (Sambrook et al., 1989). Pseudomonas sp. M18 and its derivatives were incubated at $28^{\circ} \mathrm{C}$ in King's medium B (KMB; King et al., 1954). Normal growth conditions for strain M18 and its derivatives were as follows: one colony was inoculated into a $250 \mathrm{ml}$ flask containing $25 \mathrm{ml} \mathrm{KMB}$ broth, and grown at $28^{\circ} \mathrm{C}$, with shaking at 220 r.p.m., in a C25KC incubator shaker (New Brunswick Scientific). After $10 \mathrm{~h}$ growth, $7.5 \mathrm{ml}$ of each strain was transferred to a $500 \mathrm{ml}$ flask containing $150 \mathrm{ml} \mathrm{KMB}$ broth, and shaken at $28^{\circ} \mathrm{C}$, as described above. Antibiotics were used at the following concentrations $\left(\mu \mathrm{g} \mathrm{ml}^{-1}\right)$ : for pseudomonads, gentamicin (Gm) 40, kanamycin (Km) 50, spectinomycin (Sp) 100, and tetracycline (Tc) 125; for E. coli, Km 50, Gm 15, ampicillin (Ap) 100.

DNA manipulation and cloning procedures. Restriction endonucleases, DNA-modifying enzymes, Taq and $P f u$ DNA polymerase, DNA molecular mass markers, and other associated products, were used as recommended by the manufacturer (TaKaRa; MBI Fermentas). Small-scale preparations of plasmid DNA were performed using the MiniBEST plasmid purification kit version 2.0 (TaKaRa). Genomic DNA was extracted and purified from Pseudomonas sp. M18 using an EZ spin column genomic DNA isolation kit (Sangon). Restriction enzyme digestions, ligations, and agarose gel electrophoresis, were performed using standard methods (Sambrook et al., 1989). Restriction fragments were purified from agarose gels using the DNA gel extraction kit (V-gene Biotech). Primers used are listed in Table 1. PCR products were recovered, and directly sequenced at the Sangon Biological Engineering Technology and Service (Shanghai, China).

Plasmid and mutant construction. Genomic DNA from strain M18-T510 was digested with the restriction enzyme PstI, and the DNA fragment containing the $\mathrm{Km}^{\mathrm{r}}$ cassette from the transposon mini-Tn5 lacZ-tet/ 1 and the partial downstream flanking sequence was visualized via routine Southern hybridization, as described (Sambrook et al., 1989). The probe used was a $1.7 \mathrm{~kb} \mathrm{XbaI} \mathrm{fragment}$ containing the $\mathrm{Km}^{\mathrm{r}}$ cassette from plasmid pVDL24 (de Lorenzo et al., 1993). The $\mathrm{Km}^{\mathrm{r}}$ cassette was located on a $2.3 \mathrm{~kb}$ Pst I fragment from the genomic DNA of strain M18-T510. This PstI fragment was cloned into pBLS, creating the plasmid pBLST510 (Table 1). The nucleotide sequence of chromosomal DNA downstream of the insertion junction was determined using the primer PSRMTN5 (Table 1).

The RhlI coding region was amplified with $P f u$ polymerase from $1 \mathrm{ng}$ Pseudomonas sp. M18 chromosomal DNA using primers PRSMRHLI1 and PRSMRHLI2 (Table 1), under the following cycling conditions: one initial step of $5 \mathrm{~min}$ at $94^{\circ} \mathrm{C} ; 30$ cycles of $94^{\circ} \mathrm{C}$ for $30 \mathrm{~s}, 58^{\circ} \mathrm{C}$ for $30 \mathrm{~s}$, and $72{ }^{\circ} \mathrm{C}$ for $3 \mathrm{~min}$; followed by one final step of $5 \mathrm{~min}$ at $72{ }^{\circ} \mathrm{C}$. The resulting $2.0 \mathrm{~kb}$ PCR product was purified and digested with $\mathrm{Xba \textrm {I }}$ and HindIII, and cloned into plasmid pBLS to create pBLSRHLI (Table 1). A $1.6 \mathrm{~kb}$ PCR product including rhlR and partial flanking sequences was obtained in a similar manner using primers PRSMRHLR1 and PRSMRHLR2 (Table 1). The $1.6 \mathrm{~kb}$ PCR product was purified and digested with EcoRI and Pst $\mathrm{I}$, and cloned into the plasmid pEX18Tc, resulting in plasmid pEXTcRHLR (Table 1). Subsequently, a $1.9 \mathrm{~kb}$ Bam HI-HindIII fragment containing the intact rhlI gene, and a $1.6 \mathrm{~kb}$ EcoRI-PstI fragment containing an intact rhlR gene, were cloned into pME6000 to produce plasmids pME6000rhlI and pME6000rhlR, respectively (Table 1). 
Table 1. Bacterial strains, plasmids and primers used in this study

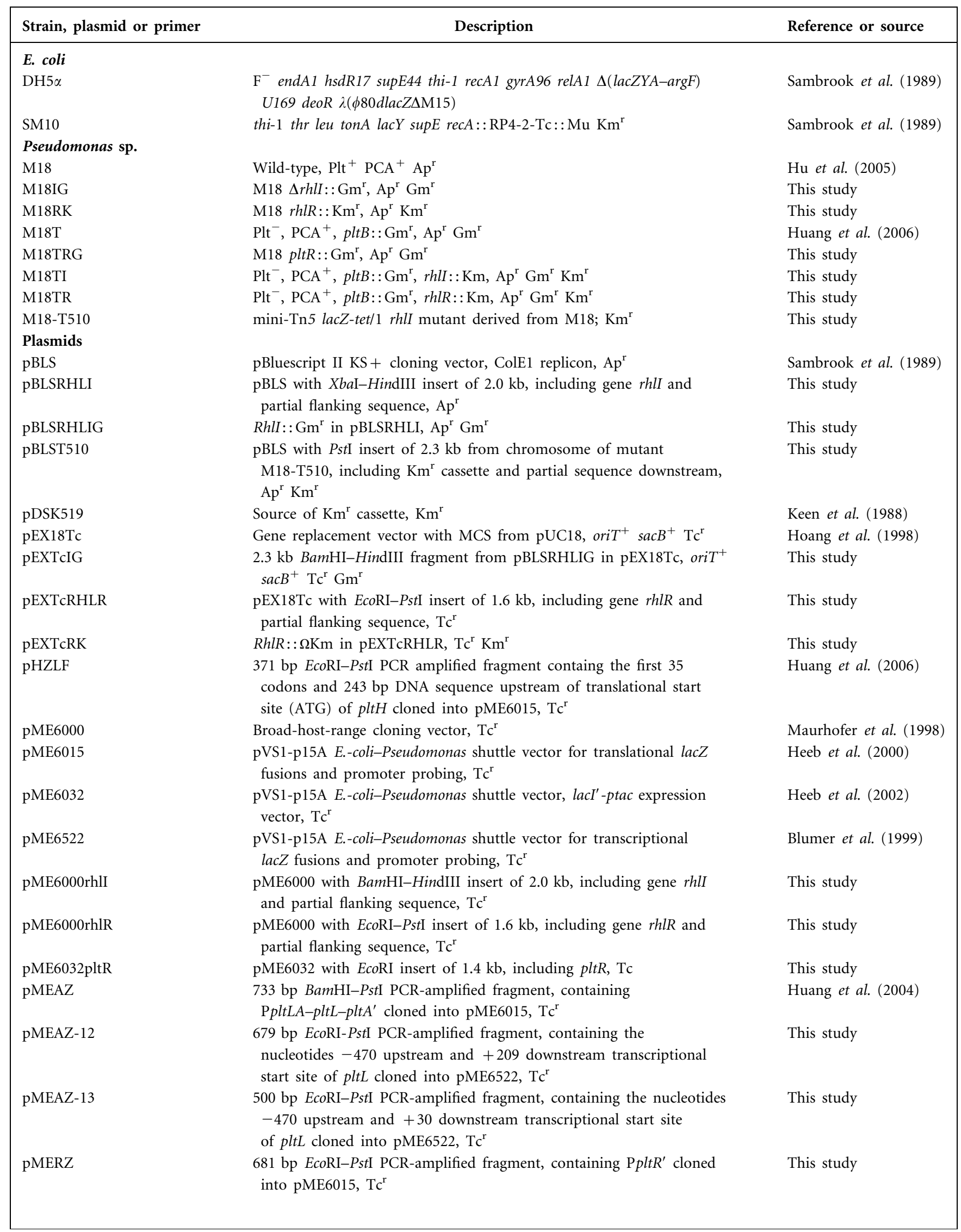


Table 1. cont.

\begin{tabular}{|c|c|c|}
\hline Strain, plasmid or primer & Description & Reference or source \\
\hline pMEZA & $\begin{array}{l}724 \text { bp BamHI-PstI PCR-amplified fragment, containing PphzA' } \\
\text { cloned into pME6015, } \mathrm{Tc}^{\mathrm{r}}\end{array}$ & Ge et al. (2004) \\
\hline Oligonucleotides & Sequence $\left(5^{\prime}-3^{\prime}\right)^{*}$ & \\
\hline PRSMPLTA1 & ACCGAGACCATCACCAGCATC & This study \\
\hline PRSMRHLI2 & GTAATAAAGCTTGAAACGCGCTTCTTCGCTACAG (HindIII) & This study \\
\hline PRSMRHLR1 & GTCATCCTGCAGAGCCTTGCTGCCATCGT (EcoRI) & This study \\
\hline PRSMRHLR2 & AGCGATGAATTCGGTCGTCGGCAACAG (PstI) & This study \\
\hline PSRMRPOD1 & GAGCGGGAGGAGCGTTTAC & This study \\
\hline PSRMRPOD2 & CGGGCAAAAAATAAGCAGAGG & This study \\
\hline
\end{tabular}

${ }^{\star}$ Specified restriction sites are underlined.

To construct the rhlI mutant, a $557 \mathrm{bp} B g l \mathrm{II}-E c 091 \mathrm{I}$ fragment from pBLSRHLI, including the partial sequence of the rhlI gene with its promoter region, was replaced by an $850 \mathrm{bp} \mathrm{SmaI} \mathrm{fragment} \mathrm{containing}$ the aacC1 gene from plasmid pUCGM, to create plasmid pBLSRHLIG (Table 1, Fig. 2). Next, a $2.2 \mathrm{~kb}$ BamHI-HindIII fragment from pBLSRHLIG was cloned into pEX18Tc to generate the plasmid pEXTcRG (Table 1). After conjugation with strain M18 as the recipient, and E. coli SM10/pEXTcRG as the donor, we selected Tcsensitive, Gm-resistant and sucrose-resistant transconjugants with an inactivated rhlI gene in the chromosome. One isolate (M18IG) was further confirmed by PCR for the additional $123 \mathrm{bp}$ fragment in the rhlI gene using primers PRSMRHLI1 and PRSMRHLI2. The rhlI gene in the Plt-negative strain M18T was inactivated by inserting the $\Omega \mathrm{Km}$ Km-resistance cassette of pDSK519 into the PstI site of the ORF of the rhlI gene (mutant M18TI). The plasmid pME6000rhlI was introduced into strain M18IG, forming the complemented rhlI mutant M18IG/ pME6000rhlI.

To construct the rhlR mutant, the $1.7 \mathrm{~kb} \Omega \mathrm{Km}$ cassette was inserted into the rhlR gene at the SacI site in pEXTcRHLR, resulting in pEXTcRK (Table 1). Analogous to the rhlI mutant construction described above, we constructed the rhlR mutant M18RK (Fig. 2), and the M18T derivative M18TR. Successful inactivation of rhlR was further verified by PCR. Plasmid pME6000rhlR was introduced into the strain M18RK, forming the complemented rhlR mutant M18RK/ pME6000rhlR.

RNA extraction and reverse transcription. RNA was extracted from M18, M18IG, M18RK, and the complemented mutants M18IG and M18RK. Under normal growth conditions, each culture was harvested in early exponential phase, at an $\mathrm{OD}_{600}$ of $2.0-2.4$, or in late exponential phase, at an $\mathrm{OD}_{600}$ of 5.0-6.0. RNA extraction and reverse transcription were performed using the EZ spin column total RNA isolation kit (Sangon), and the First Strand cDNA synthesis kit (MBI Fermentas), according to manufacturers' recommendations.

Real-time PCR. The amounts of cDNA obtained by reverse transcription were quantified utilizing the MiniOpticon Real-Time PCR System (Bio-Rad), with a SYBR green I stain. We measured the transcription of the pltA gene, which is the first gene of the Plt biosynthetic gene cluster in Pseudomonas sp. M18 (Huang et al., 2004; Nowak-Thompson et al., 1999). Transcription of the endogenous housekeeping gene $r p o D$ (Savli et al., 2003) was used as a reference. The primers used for amplifying the pltA gene (PRSMPLTA1 and PRSMPLTA2) and the rpoD gene (PSRMRPOD1 and PSRMRPOD2) were designed from their sequences in Pseudomonas sp. M18 (Table 1). The PCR fragments of the rpoD gene and pltA gene were 173 and $157 \mathrm{bp}$, respectively. Each $25 \mu \mathrm{l}$ of reaction mixture contained: $2 \mu \mathrm{l}$ of the cDNA sample diluted $1: 5 ; 1 \times$ PCR buffer; $1 \times$ SYBR green I; $200 \mu \mathrm{M}$ dATP, dGTP, dCTP and dTTP; $1 \mu \mathrm{M}$ of each primer in water; and $2.5 \mathrm{U}$ Taq DNA polymerase. Negative controls consisting of distilled water, or total RNA instead of the cDNA, were included in each test to check for DNA contamination. The target cDNA ( pltA) and reference cDNA $(r p o D)$ were amplified in separate wells. PCRs were run in an MJ Mini Personal Thermal Cycler (Bio-Rad), with the following program: one step of 5 min at $94^{\circ} \mathrm{C} ; 30$ cycles of $94^{\circ} \mathrm{C}$ for $30 \mathrm{~s}, 58^{\circ} \mathrm{C}$ for $30 \mathrm{~s}$, and $72^{\circ} \mathrm{C}$ for $30 \mathrm{~s}$. The evolution of fluorescence intensity of each reaction mixture was recorded continuously using a MiniOpticon detector (Bio-Rad). The PCR products amplified from cDNA were further confirmed by sequencing. PCR analyses for each strain in different growth phases were repeated three times.

For analysis of the data, the comparative threshold cycle $\left(C_{\mathrm{T}}\right)$ method was adopted as a mathematical model, as described by Livak \& Schmittgen (2001), to calculate the differences of pltA gene expression among different strains grown in KMB broth. The amount of pltA cDNA, normalized to levels of the reference $r p o D$, and calibrated relative to the M18 strain, was expressed as a $2^{-\Delta \Delta C_{\mathrm{T}}}$ value, which represents the fold change of $p l t A$ gene expression in a given strain relative to strain M18. The $\Delta \Delta C_{\mathrm{T}}$ value was the $\Delta C_{\mathrm{T}}$ value of a certain strain (M18, M18IG, M18RK, or the complemented M18IG or M18RK) subtracted from the $\Delta C_{\mathrm{T}}$ value of strain M18, where $\Delta C_{\mathrm{T}}$ is the $C_{\mathrm{T}}$ value of cDNA ( $p l t A$ gene) subtracted from the $\Delta C_{\mathrm{T}}$ value of the cDNA ( $r p o D$ gene) in each strain. Statistical significance was computed by an unpaired Student's $t$ test; $P<0.05$ was considered statistically significant.

Assays for BHL, $\boldsymbol{N}$-hexanoylhomoserine lactone, PIt and $\boldsymbol{\beta}$ galactosidase. For extraction of AHL, a $1 \mathrm{ml}$ culture of M18 strain or one of its derivatives (M18-T510, M18IG or M18IG/ pME6000rhlI) was harvested at an $\mathrm{OD}_{600}$ of 5.0-6.0. After centrifugation $(8000 \mathrm{~g})$, the supernatant was extracted three times with $1 \mathrm{ml}$ ethyl acetate. The ethyl acetate was evaporated with a rotary evaporator, and dried extracts containing AHL were resuspended in $20 \mu$ l ethyl acetate. BHL and $N$-hexanoylhomoserine lactone (HHL) were analysed employing a TLC bioassay, as described by McClean et al. (1997) and Shaw et al. (1997). Four samples, and standard 

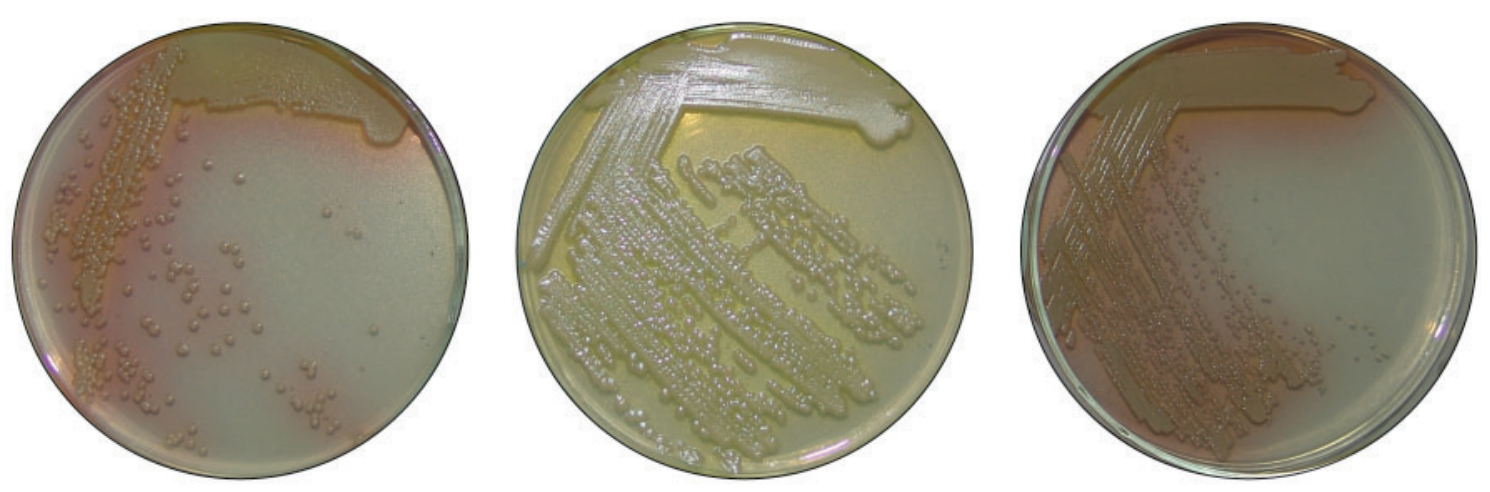

Fig. 1. Pigments produced by the strains M18 (left), M18-T510 (middle) and the complemented mutant M18IG/pME6000rhll (right) grown on KMB agar.

AHLs (Fluka), were spotted $(2 \mu \mathrm{l})$ onto TLC silica Gel RP-C18 plates (Merck) for migration, and Chromobacterium violaceum CV026 was used as the reporter strain (McClean et al., 1997; Shaw et al., 1997). The quantities of BHL and HHL in each sample were estimated in comparison with standards, i.e. 0.25, 0.5, 1 and $2 \mathrm{nmol}$ BHL, and 0.01, 0.1, 0.2 and $0.5 \mathrm{nmol} \mathrm{HHL}$.

The extraction and quantification of Plt from the culture suspension were performed using the methods described by Huang et al. (2004). $\beta$ Galactosidase assays were done according to the method of Miller (Sambrook et al., 1989).

\section{RESULTS}

\section{Characterization of the chromosome region flanking the transposon in M18-T510}

Pseudomonas sp. M18 produces an uncharacterized red pigment when streaked on KMB plates (Fig. 1). In previous experiments, we obtained a mini-Tn5 lacZ-tet/ 1 mutant (M18-T510) that could not produce observable levels of this red pigment (Fig. 1). The fragment containing the inserted $\mathrm{Km}$ cassette of the mini-Tn5 lacZ-tet/1, along with downstream chromosomal DNA, was cloned and sequenced. For strain M18-T510, sequence analysis of plasmid pSK-T510 revealed that the partial sequence downstream of the transposon shared $98 \%$ identity with the rhlI gene (accession no. PA3476) of $P$. aeruginosa PAO1. In strain PAO1, rhlI encodes an enzyme related to the synthesis of BHL and HHL (Jiang et al., 1998). Considering such a remarkable level of identity, we gave the name rhlI to the gene from M18-T510. A pair of conservative primers was designed according to the nucleotide sequence flanking the rhlI gene in $P$. aeruginosa PAO1 (www.pseudomonas.com). A $2.0 \mathrm{~kb}$ PCR fragment from the chromosomal DNA of the wild-type M18 strain was purified, sequenced and cloned (see Methods). The full sequence of the $2.0 \mathrm{~kb}$ DNA fragment shared $99 \%$ identity with a region of $P$. aeruginosa PAO1. The M18 rhlI gene was flanked upstream by sequence similar to $r h l R$, and downstream by pheC; this arrangement is identical to that in $P$. aeruginosa PAO1 (Ochsner \& Reiser, 1995). The transposon was located at position 46 in the rhll ORF (Fig. 2). The deduced product (201 aa) of the M18 strain rhlI gene shared $98 \%$ similarity with the RhlI protein of $P$. aeruginosa PAO1. The intact rhlR gene was also sequenced and cloned (see Methods), and the predicted protein sequence of RhlR showed $100 \%$ identity to the transcriptional regulator RhlR (PA3477) of P. aeruginosa PAO1.

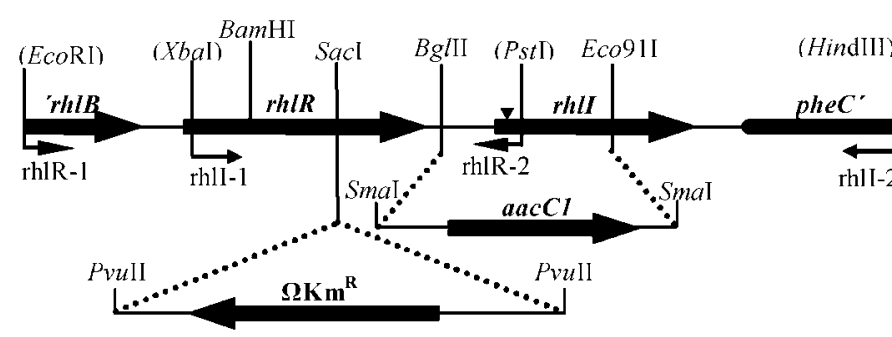

M18

M18IG

M18RK
Fig. 2. Physical location of the $r h / R$ and $r h / l$ genes in the chromosome of Pseudomonas $\mathrm{sp}$. M18. Artificial restriction sites on primers (rhIR-1 and rhIR-2) used for cloning rh/R and primers (rhll-1 and rhll-2) for rhll are shown in parentheses. The Bg/ll-Eco91l fragment containing the partial sequence of the rhll gene of strain M18 was replaced by a Smal fragment containing the aacC1 gene to construct the rhll mutant M18IG. A $1.7 \mathrm{~kb} \Omega \mathrm{Km}$ cassette was inserted into the rh/R gene at the Sacl site, resulting in the rhIR mutant M18RK. The filled inverted triangle indicates the insertion site of mini-Tn5 lacZ-tet/1 in strain M18-T510. 
Furthermore, the 16S rRNA gene sequence of strain M18 (AY696302) shares $99 \%$ identity with $P$. aeruginosa PAO1 (Hu et al., 2005). However, some distinct characters, such as plt genes, red pigment production (Fig. 1), and notable high levels of PCA production (Hu et al., 2005), were markedly different from strain PAO1. Together, these data indicate that Pseudomonas sp. M18 is an unusual pseudomonad that is closely related to $P$. aeruginosa $\mathrm{PAO}$, but not identical to it (Hu et al., 2005).

\section{Effects of the rhll null mutation on the synthesis of AHLs and red pigment}

The effect of the rhlI mutation on AHL production in Pseudomonas sp. M18 was measured. A null mutant with an inactivated chromosomal rhlI gene was constructed by inserting a single $\mathrm{Gm}$-resistance cassette by homologous recombination. The partial nucleotide sequence and promoter region of the rhlI gene from the wild-type strain M18 was deleted, and replaced with a fragment containing the aacC1 gene, which is responsible for $\mathrm{Gm}$ resistance, to generate an rhlI mutant designated M18IG (Fig. 2). TLC assays indicated that strain M18IG, as compared with wildtype M18, could not produce detectable amounts of BHL or $\mathrm{HHL}$ in KMB broth when grown to an $\mathrm{OD}_{600}$ of 5.0-6.0; these results are similar to those for strain M18-T510 (Fig. 3). The inactivated rhlI in M18IG resulted in the disappearance of red pigment (data not shown), which is also similar to the rhlI mutant M18-T510 (Fig. 1). In contrast, the complemented mutant M18IG/pME6000rhlI restored the ability to produce the two AHLs (Fig. 3) and the red pigment (Fig. 1).

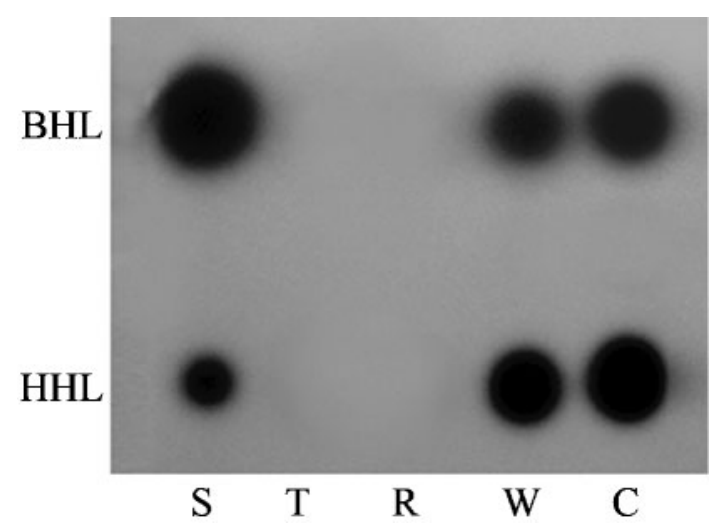

Fig. 3. TLC analysis of AHLs secreted by the wild-type Pseudomonas sp. M18 (W), mutant M18-T510 (T), mutant M18IG (R), and its complemented mutant M18IG/pME6000rhll (C). The AHLs in each sample were concentrated to 50-fold more than the actual concentration in each culture after the cells had grown to an $\mathrm{OD}_{600}$ of 5.0-6.0. The AHL biosensor Chromobacterium violaceum CV026 was used to detect BHL and $\mathrm{HHL}$. Lane $\mathrm{S}$ contains $\mathrm{BHL}(2 \mathrm{nmol})$ and $\mathrm{HHL}(0.02 \mathrm{nmol})$ standards.

\section{Effect of the rhl QS system on PIt production}

To investigate the regulatory function of the putative $r h l \mathrm{QS}$ system (RhlR and RhlI) on Plt production in Pseudomonas sp. M18, the chromosomal rhlR gene in strain M18 was inactivated by inserting a $\Omega \mathrm{Km}$ cassette (Fig. 2 ) into the SacI site of the rhlR gene, resulting in a mutant that was named M18RK. Inactivation of either rhlI or rhlR resulted in a dramatic increase of Plt production in strains M18IG and M18RK compared with the wild-type strain. The quantities of Plt produced by strains M18IG and M18RK were nearly identical, and were both greater than strain M18 over the same time course of growth (Fig. 4a). The expression of the Plt biosynthetic genes in the M18, M18IG and M18RK strains had to be determined in parallel. To this end, the plasmid pMEAZ harbouring a plt $A^{\prime}-{ }^{\prime}$ lac $Z$ translational fusion was introduced into each of these three strains, and $\beta$ galactosidase activity was assayed in each of them. The expression of the $p l t A^{\prime}-^{\prime}$ lac $Z$ fusion increased fivefold after $24 \mathrm{~h}$ growth in KMB broth for both M18IG and M18RK compared with strain M18 (Fig. 4b).

Our results were further confirmed by an in trans complementation experiment in KMB broth. The level of Plt produced by strain M18IG containing pME6000rhlI plasmid, and strain M18RK containing pME6000rhlR, was restored to that of the wild-type strain M18 (Fig. 4a). These complementation experiments demonstrated that the increased Plt production was indeed due to inactivation of either the rhlI or the rhlR gene in these mutant strains, and not to any other genetic event.

\section{Effect of the rhl QS system on pltA expression occurs at the transcriptional level}

Genetic evidence has revealed that RhlR regulates certain QS-controlled genes at the transcriptional level (Fuqua et al., 2001). This evidence suggests that the $r h l$ QS system may also regulate expression of Plt biosynthetic genes at the transcriptional level.

To confirm this hypothesis, the mRNA levels of pltA in M18, M18IG and M18RK were assessed by real-time PCR in two different growth phases. The housekeeping gene $r p o D$ was assayed in parallel to normalize transcript levels of pltA. As PltA is a key component of Plt biosynthesis (Huang et al., 2004; Nowak-Thompson et al., 1999), the mRNA level of pltA can be taken as representative of the transcriptional expression of the plt gene cluster. The relative mRNA expression levels of the $p l t A$ were analysed by the $2^{-\Delta \Delta C_{\mathrm{T}}}$ method, as described in Methods. According to Table 2, the level of pltA transcription increased in strains M18RK and M18IG, as compared with strain M18 and the complemented mutant, in both the early exponential phase $(P<0.05)$ and the late exponential phase $(P<0.05)$. In the early exponential phase, the normalized pltA levels in strains M18IG and M18RK were 1.61 and 1.92, respectively, relative to strain M18. Even greater amounts were observed when cells reached an $\mathrm{OD}_{600}$ of 5.0-6.0 in late exponential 

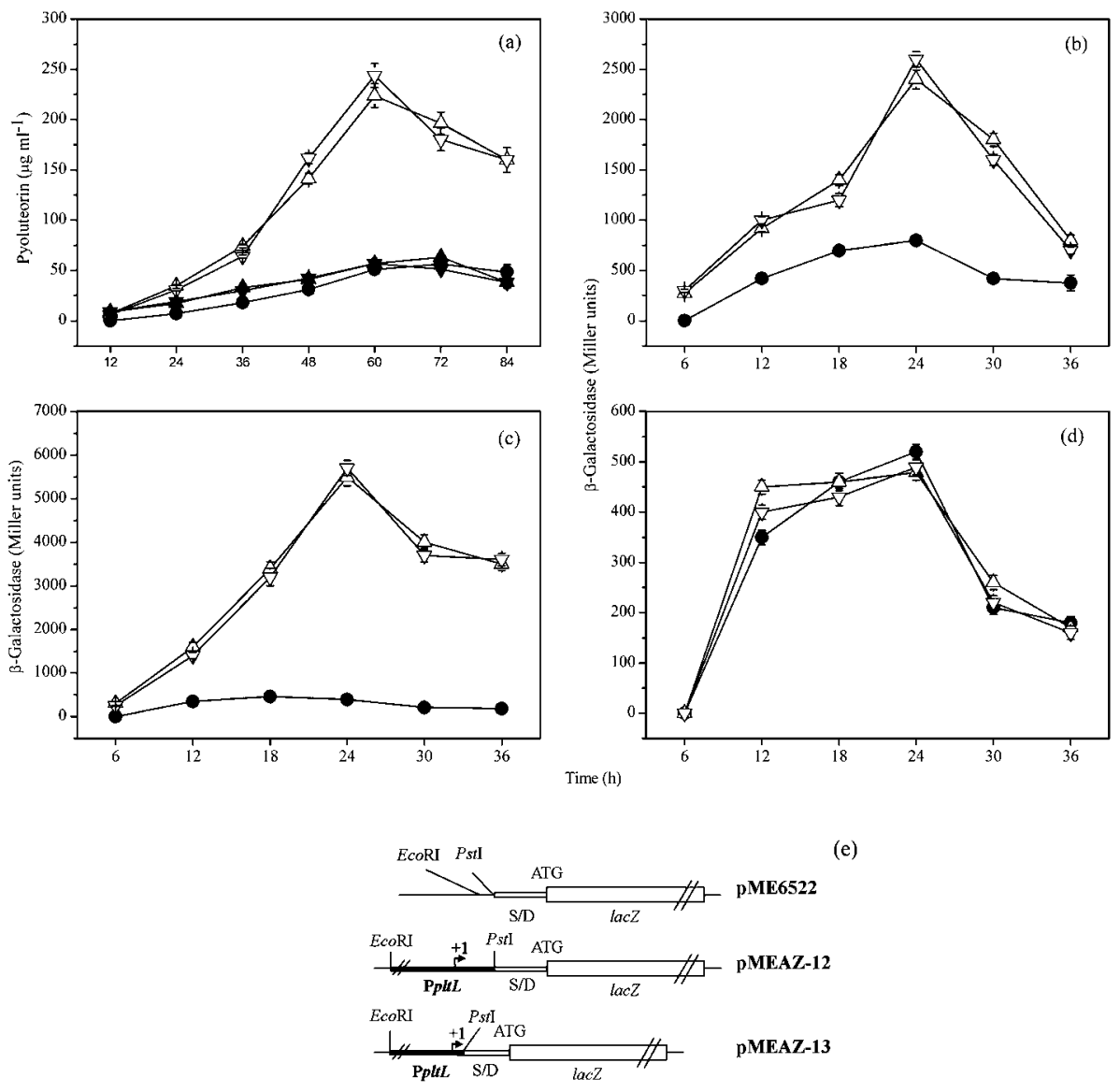

(e)

Fig. 4. Effect of $r h / R$ and $r h / l$ genes on Plt production and expression levels of the Plt biosynthetic gene cluster. (a) Plt was quantified in strains M18 $(\bullet), M 18 I G(\triangle), M 18 R K(\nabla)$, the complemented M18IG $(\mathbf{\Delta})$ and the complemented M18RK $(\boldsymbol{\nabla})$, in KMB broth. $\beta$-Galactosidase expression (Miller units) of the plt $A^{\prime}-{ }^{\prime}$ lac $Z$ translational fusion expression plasmid pMEAZ (b), the plt'-lacZ transcriptional fusion expression plasmid pMEAZ-12 (c), and the plt-lacZ transcriptional fusion expression plasmid pMEAZ-13 (d), was followed over time in cultures of wild-type M18 (๑), M18IG $(\triangle)$ and M18RK $(\nabla)$. Values are the means $( \pm S D$ ) for triplicate cultures. (e) Maps of the plt'-lacZ transcriptional fusion expression plasmid pMEAZ-12, and the plt-lacZ transcriptional fusion expression plasmid pMEAZ-13. S/D, putative Shine-Dalgarno sequence. +1 , putative transcriptional start site of the pltL. The putative promoter region of $p / t L$ and its flanking sequence are shown as a thick black line.

Table 2. Analysis of relative $p / t A$ transcriptional levels in early exponential phase $\left(O D_{600}\right.$ between 2.0 and 2.4$)$ and late exponential phase $\left(\mathrm{OD}_{600}\right.$ between 5.0 and 6.0) for strains of M18, M18IG, complemented M18IG, M18RK, and complemented M18RK, using real-time quantitative PCR

\begin{tabular}{|c|c|c|c|c|c|c|c|c|}
\hline \multirow[t]{2}{*}{ Strain } & \multicolumn{4}{|c|}{ Early exponential phase } & \multicolumn{4}{|c|}{ Late exponential phase } \\
\hline & $C_{\mathrm{T}, \mathrm{rpoD}}{ }^{*}$ & $C_{\mathrm{T}, \mathrm{pltA}}{ }^{*}$ & $\Delta C_{\mathrm{T}}^{\dagger}$ & $2^{-\Delta \Delta C_{\mathrm{T}}} \ddagger$ & $C_{\mathrm{T}, \mathrm{rpoD}}{ }^{*}$ & $C_{\mathrm{T}, \mathrm{pltA}}{ }^{*}$ & $\Delta C_{\mathrm{T}}^{\dagger}$ & $2^{-\Delta \Delta C_{\mathrm{T}}} \ddagger$ \\
\hline M18 & $21.10 \pm 0.09$ & $22.40 \pm 0.22$ & $1.30 \pm 0.11$ & $1.00(0.93-1.08)$ & $18.96 \pm 0.13$ & $19.73 \pm 0.12$ & $0.77 \pm 0.09$ & $1.00(0.94-1.06)$ \\
\hline M18IG & $20.94 \pm 0.17$ & $21.55 \pm 0.10$ & $0.61 \pm 0.08$ & $1.61(1.53-1.71)$ & $18.42 \pm 0.14$ & $16.79 \pm 0.07$ & $-1.63 \pm 0.06$ & $5.03(4.82-5.24)$ \\
\hline Complemented M18IG & $21.44 \pm 0.21$ & $22.64 \pm 0.15$ & $1.20 \pm 0.12$ & $1.07(0.99-1.16)$ & $18.72 \pm 0.06$ & $19.27 \pm 0.19$ & $0.55 \pm 0.10$ & $1.16(1.09-1.25)$ \\
\hline M18RK & $20.62 \pm 0.12$ & $20.98 \pm 0.09$ & $0.36 \pm 0.11$ & $1.92(1.78-2.07)$ & $19.14 \pm 0.32$ & $17.87 \pm 0.23$ & $-1.27 \pm 0.13$ & $4.41(4.03-4.82)$ \\
\hline Complemented M18RK & $21.25 \pm 0.24$ & $22.67 \pm 0.05$ & $1.42 \pm 0.08$ & $0.92(0.87-0.97)$ & $18.43 \pm 018$ & $19.06 \pm 0.09$ & $0.63 \pm 0.11$ & $1.10(1.02-1.19)$ \\
\hline
\end{tabular}

${ }^{*}$ Values are means $( \pm \mathrm{SD})$ for three independent experiments.

$\dagger \Delta C_{\mathrm{T}}=$ mean $C_{\mathrm{T}, \mathrm{pltA}}-$ mean $\mathrm{C}_{\mathrm{T}, \mathrm{rpoD}}$.

$\ddagger 2^{-\Delta \Delta C_{\mathrm{T}}}$, Normalized amount of cDNA from the pltA gene in different strains relative to that in wild-type M18; $\Delta \Delta C_{\mathrm{T}}=$ mean $\Delta C_{\mathrm{T}}-$ mean $\Delta C_{\mathrm{T}, \mathrm{M} 18}$. 
phase, and the normalized pltA levels in M18IG and M18RK reached 5.03 and 4.41 , respectively.

Using NNPP (Promoter Prediction by Neural Network; Reese, 2001), we predicted the putative promoter and transcriptional start site to be $254 \mathrm{bp}$ upstream of the translational start site (ATG) of pltL (data not shown). Thus, the plasmid pMEAZ-12, harbouring the transcriptional $p l t^{\prime}-l a c Z$ fusion, which contains the nucleotides -470 upstream and +209 downstream of the transcriptional start site (Fig. 4e), was introduced into M18, M18RK and M18IG. We then assayed $\beta$-galactosidase activity in each strain. The transcriptional expression of the $p l t^{\prime}-l a c Z$ fusion in strains M18RK and M18IG was significantly enhanced, and was 10 -fold higher than strain M18 in KMB broth during some growth phases (Fig. 4c). These data, together with the results from real-time PCR, show that the expression of the Plt biosynthetic genes is negatively controlled by the rhl QS system at the transcriptional level. Another plasmid, pMEAZ-13, carrying a different transcriptional $p l t^{\prime}-l a c Z$ fusion, containing 470 bases upstream, but only 30 bases downstream of the transcriptional start site (Fig. 4e), was constructed, and introduced into the M18, M18RK and M18IG strains. It is interesting that the transcription of the $p l t^{\prime}-l a c Z$ fusion in these three strains was similar (Fig. 4d).

\section{Differential contributions of BHL and $\mathrm{HHL}$ to the regulation of PIt production}

RhlI in strain M18 was able to synthesize BHL and HHL at a ratio of approximately 10:1 in KMB broth; the concentrations of BHL and HHL, estimated by comparison with standards, reached maximum concentrations of 10 and $1 \mu \mathrm{M}$, respectively, during late exponential phase $\left(\mathrm{OD}_{600}\right.$ between 5.0 and 6.0).

An AHL-supplementation experiment was carried out to investigate the respective contributions of BHL and HHL to Plt production in Pseudomonas sp. M18 in KMB broth. BHL and HHL were added to separate M18IG cultures at an $\mathrm{OD}_{600}$ of 2.4 before synthesis of AHL (BHL and HHL) is normally initiated in strain M18 (data not shown). The final concentrations of BHL and HHL in the M18IG cultures were 15 and $1.5 \mu \mathrm{M}$, respectively; both values were 1.5 -fold higher than the estimated maximum values produced in M18 cultures, as described above. At the same time, another M18IG culture was treated with an equal volume of ethyl acetate vehicle to dissolve the AHLs, as a negative control. When cells entered late exponential phase $\left(\mathrm{OD}_{600}\right.$ between 5.0 and 6.0), Plt production in the three different M18IG cultures was measured, and the results are presented in Fig. 5. In the M18IG culture supplemented with BHL, the concentration of Plt declined to $57 \mu \mathrm{g} \mathrm{ml}^{-1}$ compared with $230 \mu \mathrm{g} \mathrm{ml}^{-1}$ in the M18IG culture treated with ethyl acetate alone. Similarly, addition of HHL to the M18IG culture led to decreased Plt production $\left(119 \mu \mathrm{g} \mathrm{ml}^{-1}\right)$, but the extent of the reversion was much less than in the BHL-treated culture. Furthermore, increasing the concentration of each AHL to

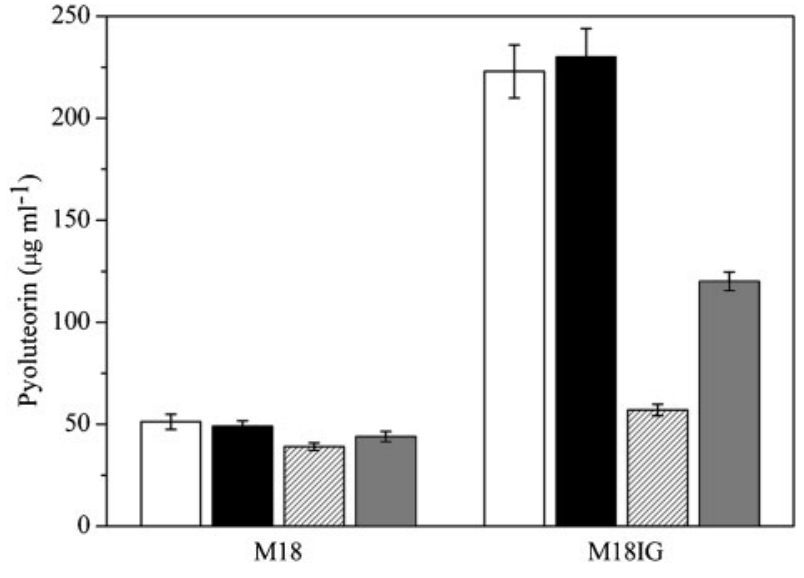

Fig. 5. Effect of BHL and HHL on Plt production. Plt production was assayed in strain M18 and the rhll mutant M18IG in $\mathrm{KMB}$ broth, and KMB supplemented with ethyl acetate (black bars), BHL (hatched bars) and HHL (grey bars) after the culture had entered late exponential phase $\left(\mathrm{OD}_{600}\right.$ between 5.0 and 6.0). The final concentrations of $\mathrm{BHL}$ and $\mathrm{HHL}$ added into the M18IG culture were 15 and $1.5 \mu \mathrm{M}$, respectively. White bars, blank.

threefold more than in the wild-type caused a similar trend of differential decreases in Plt production $\left(52 \mu \mathrm{g} \mathrm{ml}^{-1}\right.$ for BHL, and $108 \mu \mathrm{g} \mathrm{ml}^{-1}$ for HHL).

\section{The activator PItR mediates repression of the PIt biosynthetic gene cluster expression by the rhl QS system}

A putative transcriptional activator, PltR, has been recently identified upstream of the Plt biosynthetic genes (Huang et al., 2004), and the deduced peptide sequence (343 aa) exhibited $63 \%$ identity over 313 aa to the homologous PltR protein in P. fluorescens Pf-5 (Nowak-Thompson et al., 1999).

The pltR mutant M18TRG was constructed (data not shown), and the levels of Plt in the culture of the wild-type M18 and mutant M18TRG were quantified at an $\mathrm{OD}_{600}$ of 5.0-6.0 (late exponential phase). The inactive pltR mutant (M18TRG) showed significantly decreased Plt production (Fig. 6b). The empty plasmid pME6032, and the pltR overexpression plasmid pME6032pltR (Fig. 6a), were introduced into the mutant M18TRG. Following induction with IPTG, the quantity of Plt in culture of mutant M18TGR harbouring pME6032 plasmid was $9.0 \mu \mathrm{g} \mathrm{ml}^{-1}$, which was similar to that of the mutant alone $\left(12 \mu \mathrm{g} \mathrm{ml}^{-1}\right.$, Fig. $\left.6 \mathrm{~b}\right)$. In contrast, Plt production by M18TGR harbouring the plasmid pME6032pltR increased appreciably. After IPTGinduction, the Plt expression of M18TGR, harbouring the pME6032pltR plasmid, increased to $389 \mu \mathrm{g} \mathrm{ml}^{-1}$, which was 13-fold more than wild-type strain M18 (Fig. 6b). In addition, disruption of pltR in the mutant M18TRG resulted in a notable decline in the expression of the transcriptional 


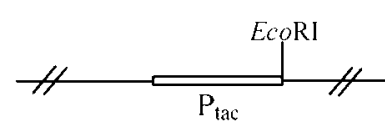

(a)
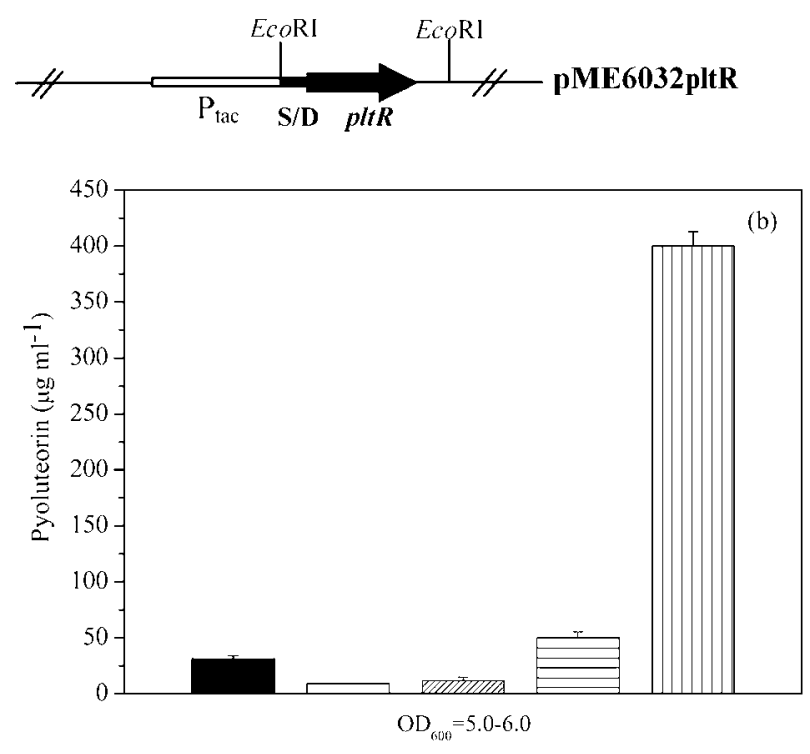

Fig. 6. (a) Construction of the pltR overexpression plasmid pME6032pltR. The $P_{\text {tac }}$ promoter is shown by the white boxes, and the pltR gene with its putative Shine-Dalgarno sequence (S/D) is shown by the thick black arrow. (b) Plt production in strain M18 carrying plasmid pME6032, the pltR mutant M18TRG carrying plasmid pME6032, and M18TRG carrying the pltR overexpression plasmid pME6032pltR, after the cells had entered late exponential phase $\left(\mathrm{OD}_{600}\right.$ between 5.0 and 6.0). IPTG was added to cultures as indicated, and the final concentration was adjusted to $1 \mathrm{mmol} \mathrm{ml}^{-1}$. Black bar, M18; white bar, M18TRG; diagonal hatched bar, M18TRG/pME6032+IPTG; horizontally hatched bar, M18TRG/pME6032pltR; vertically hatched bar, M18TRG/pME6032pltR+IPTG.

plt'-lacZ fusion carried by plasmid pMEAZ-12, for which $\beta$ galactosidase activity was 172 Miller units, as compared with M18 (450 Miller units) after $18 \mathrm{~h}$. This confirms that PltR acts as a transcriptional activator of the Plt biosynthetic gene cluster in Pseudomonas sp. M18, and it is consistent with results found in P. fluorescens Pf-5 (Nowak-Thompson et al., 1999).

Such a regulatory mechanism, together with the described relationship between Plt production and the $r h l \mathrm{QS}$ system, is reminiscent of the hypothesis that PltR may mediate repression of the Plt biosynthetic gene cluster by the $r h l \mathrm{QS}$ system. To confirm this hypothesis, expression of a plt $R^{\prime}-$ 'lacZ translational fusion (carried by pMERZ) in the M18, M18RK and M18IG strains grown in KMB broth was investigated. Mutation of either rhlR or rhlI resulted in an increase in pltR'- ${ }^{\prime}$ lac $Z$ fusion expression in the M18RK or M18IG strains, as compared with the wild-type (Fig. 7a). $\beta$ Galactosidase activity of the $p l t R^{\prime}-{ }^{\prime}$ lac $Z$ fusion expressed in either M18RK or M18IG reached a peak of about 90 Miller

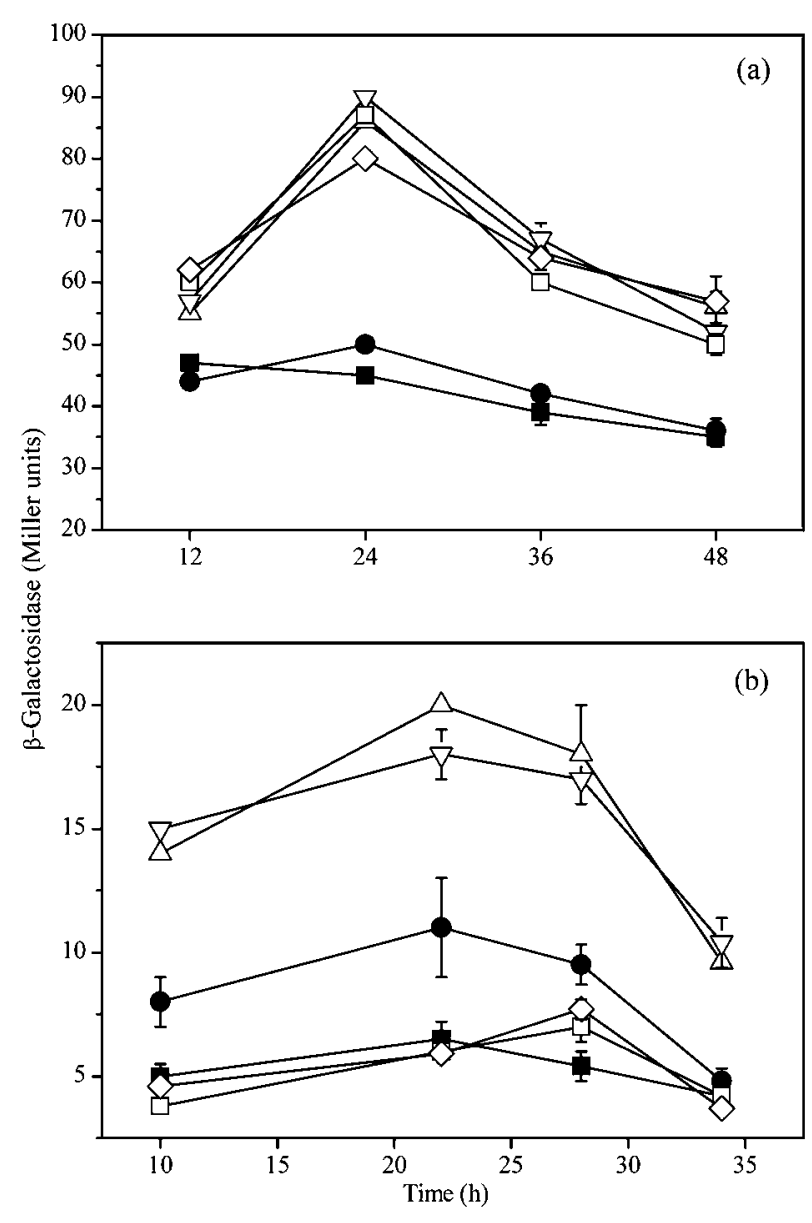

Fig. 7. Effects of the null mutation of the $r h /$ OS system on the expression of $p / t R$ and the $A B C$ transport gene cluster. Activity of $\beta$-galactosidase of a translational $p / t R^{\prime}-{ }^{\prime} l a c Z$ fusion expression plasmid pMERZ (a), and a translational $p / t H^{\prime}-{ }^{\prime} l a c Z$ fusion expression plasmid pHZLF (b), in strains M18 (๑), M18T(ם), M18IG $(\triangle)$, M18RK $(\nabla), \operatorname{M18TI}(\square)$ and M18TR $(\diamond)$ grown in KMB broth. Values are the means $( \pm S D)$ for triplicate cultures.

units after $24 \mathrm{~h}$, while the peak activity in the wild-type was less than 50 Miller units. These data indicate that inactivation of the $r h l$ QS system enhances expression of pltR.

\section{PIt-specific ABC transporter expression by the rhl QS system requires PIt}

To determine whether the rhl QS system regulates expression of the Plt-specific ABC transporter PltHIJKN, we followed expression of the $p l t H^{\prime}-{ }^{\prime}$ lac $Z$ translational fusion (carried by pHZLF) over time in strains M18, M18IG and M18RK. $\beta$-Galactosidase activity in strains M18IG and M18RK was higher than that in the wild-type during the growth process (Fig. $7 \mathrm{~b}$ ). The increase was consistent with the trend of increased Plt production in the mutant M18IG and M18RK strains, as described above. In addition, it has been reported previously that the Plt molecule itself induces 
expression of the $\mathrm{ABC}$ transport gene cluster in Pseudomonas sp. M18 (Huang et al., 2006). These results suggest that Plt might participate in this regulation. To examine this possibility, expression of a pltH'-'lacZ translational fusion was measured in the Plt-negative strain M18T, the rhlI Plt-negative mutant M18TI, and the rhlR Plt-negative mutant M18TR. $\beta$-Galactosidase activity was almost identical in each of these three mutants, and was approximately $50 \%$ of that in the wild-type M18 (Fig. 7b). The promotional effect of the rhlI mutation on the plt $H^{\prime}-$ ' lac Z reporter was clearly suppressed by the absence of Plt in the M18TI and M18TR strains.

\section{Effect of the rhl QS system on cell division and death}

Survival of the rhlR mutant M18RK was better than strain M18. The growth rates of strains M18 and M18RK were indistinguishable before the stationary phase of growth (Fig. 8a, b). However, after entering stationary phase, the cell density of strain M18 declined more quickly than that of strain M18RK after $48 \mathrm{~h}$ incubation, and the cell density of the former was only $50 \%$ of the latter at $72 \mathrm{~h}$ during the late stationary phase (Fig. 8a). Unlike the trend of decreased cell density, the population size [mean $\log$ (c.f.u. $\mathrm{ml}^{-1}$ )] of strain M18 declined, while it increased for strain M18RK, reaching $15.0 \log$ (c.f.u. $\mathrm{ml}^{-1}$ ) after $66 \mathrm{~h}$ incubation. This is much higher than the peak value of $13.0 \mathrm{log}\left(\right.$ c.f.u. $\mathrm{ml}^{-1}$ ) attained by the wild-type M18 at $48 \mathrm{~h}$ (Fig. 8b). In the complementation experiment, the growth rate and population size for the complemented mutant (M18RK/pME6000rhlR) were similar to those of the wild-type M18 strain (Fig. 8a, b). We also found similar results using strain M18IG (data not shown). This suggests that $r h l \mathrm{QS}$ is involved in longterm survival in Pseudomonas sp. M18.

\section{DISCUSSION}

Though well-known beneficial (to plants) root-colonizing bacteria, such as $P$. fluorescens $\mathrm{CHA} 0$ and Pf- 5 , produce Plt, to the best of our knowledge, an AHL-dependent QS system has not been identified in these bacteria. The red-pigmentproducing Pseudomonas sp. M18 adopted in this study also produces Plt, and the structural gene cluster encoding Plt biosynthesis has been identified in previous research (Huang et al., 2004). In this study, we identified an rhl QS system (rhlI and rhlR) in Pseudomonas sp. M18, and this provided an excellent model to study the regulatory functions of AHL-dependent QS on Plt production.

Our results demonstrate clearly that Plt production, and expression of the Plt biosynthetic genes, are negatively controlled by the rhl QS system (RhlR and RhlI) in Pseudomonas sp. M18. In P. aeruginosa, RhlR can act as either an activator or a repressor for different target genes (Medina et al., 2003). In this study, we demonstrated that RhlR acts as a repressor of Plt production by showing that chromosomal inactivation of rhlR leads to increased expression of the Plt biosynthetic genes (Fig. 4b) and, subsequently, to increased Plt production (Fig. 4a). Similar results occurred in the rhlI mutant M18IG. Furthermore, an rhlI and rhlR double mutant was phenotypically similar to the M18IG and M18RK mutant strains, with respect to both Plt production and $p l t A^{\prime}-{ }^{\prime}$ lac $Z$ fusion expression (data not shown). These data suggest that rhlI and rhlR comprise an rhl QS system, and that they function together in the negative regulation of Plt production in Pseudomonas sp. M18.

The rhlI gene was shown to be essential for the production of BHL and HHL in Pseudomonas sp. M18, based on TLC analysis results (Fig. 3). The AHL-supplementation experiment confirmed that both BHL and HHL can take part in the negative regulation of Plt production; however, it was obvious that BHL was more effective than HHL in this
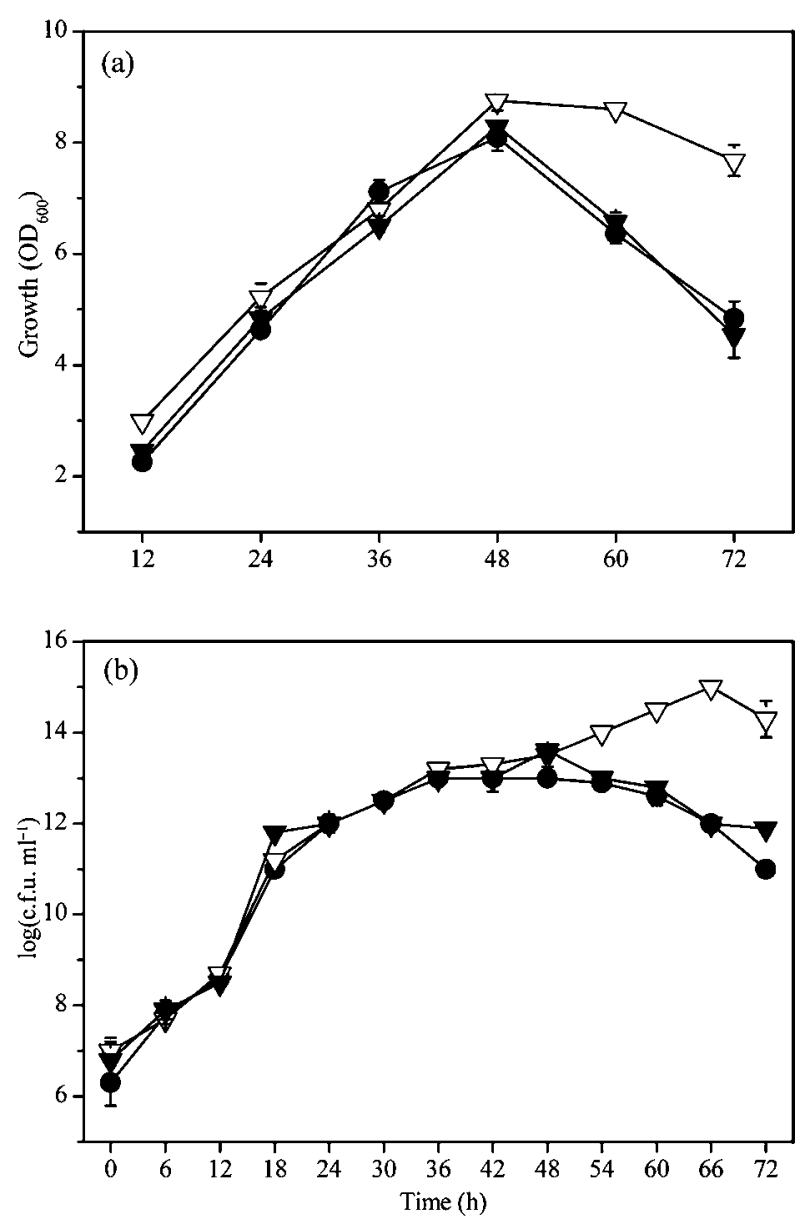

Fig. 8. Growth curves of M18, mutant M18RK, and its complemented mutant M18RK/pME6000rhIR, in KMB broth. (a) Cell densities of M18 (๑), mutant M18RK $(\nabla)$, and its complemented mutant M18RK/pME6000rhIR $(\boldsymbol{\nabla})$, were estimated by $\mathrm{OD}_{600}$ measurements. Each point represents the mean ( $\pm \mathrm{SD}$ ) of three independent measurements. (b) The population densities $\left[\log \left(\right.\right.$ c.f.u. $\left.\mathrm{ml}^{-1}\right)$ ] of these three strains in three parallel cultures were estimated by plating three selected dilutions on KMB plate. 
regulation (Fig. 5). Perhaps the explanation for this might be that RhlR interacts specifically with the BHL molecule. It seems possible that the RhlR(HHL) complex may be a redundant component in strain M18 because there is no compelling mechanism to explain its presence when another more effective RhlR(BHL) system exists. Whether the RhlR(HHL) complex controls additional genes is unknown. Furthermore, enhancement of exogenous AHL in the M18IG culture, from 1.5- to 3.0-fold more than that produced by the wild-type, failed to result in a proportional decrease in Plt production. This disproportionate effect might be explained by the degradation of exogenous AHL during the process of culturing (Chen et al., 2005), and/or the hypothesis that the relatively limiting amounts of RhlR protein were already saturated by excessive AHLs.

Our findings provide evidence that an rhl QS system negatively controls the expression of the Plt biosynthetic genes at the transcriptional level. This conclusion was drawn from two different sets of experiments. First, the transcriptional levels of Plt biosynthetic genes in strains M18IG and M18RK were enhanced as compared with the wild-type M18 strain or the complemented mutants (Table 2). Second, the expression of a transcriptional $p l t^{\prime}-l a c Z$ fusion in strains M18IG and M18RK increased as compared with the wildtype strain (Fig. 4c). More intriguingly, the $\beta$-galactosidase activity displayed a marked difference between the different transcriptional fusions (the $p l t^{\prime}-l a c Z$ carried by pMEAZ-12, and the plt-lacZ fusion carried by pMEAZ-13) when they were expressed in the same rhl-disrupted strain, such as M18IG or M18RK. The difference between the plt-lacZ and plt'-lac $Z$ fusions is that the latter has an additional $176 \mathrm{bp}$ sequence (Fig. 4e), indicating that the additional $176 \mathrm{bp}$ region may be essential for regulation of the $r h l$ QS system on Plt production, though further investigation will be required to detail the function of this region.

A pathway-specific transcriptional activator, PltR, was also identified upstream of the Plt biosynthesis genes. An inactive mutant of this protein significantly decreased both Plt production and $p l t A^{\prime}-{ }^{\prime}$ lac $Z$ fusion expression, while overexpression of pltR led to increased Plt production. Furthermore, the expression of pltR in the M18RK and M18IG strains was increased over the wild-type strain grown in KMB broth (Fig. 7a). We encountered preliminary evidence suggesting that the $r h l \mathrm{QS}$ system may function as a repressor of pltR, through which the rhl QS system negatively regulates Plt production indirectly.

In previously published work, we identified a putative $A B C$ (ATP-binding cassette) transport gene cluster ( $p l t H I J K N$ ) required for Plt production, and this was characterized within a $7.5 \mathrm{~kb}$ genomic region downstream of the antibiotic Plt biosynthetic gene cluster in Pseudomonas sp. M18 strain. Overexpression of pltHIJKN led to increased Plt production (Huang et al., 2006), suggesting that the ABC transport system may be involved in the regulatory function of the $r h l \mathrm{QS}$ system on Plt production. Using a translational $p l t H^{\prime}-{ }^{\prime} l a c Z$ fusion, we obtained preliminary evidence that mutation of either rhlI or rhlR enhanced plt $H^{\prime}-{ }^{\prime}$ lac $Z$ fusion expression (Fig. 7b). However, this enhancement disappeared when another pltB mutation was introduced. $\beta$ Galactosidase activity of the plt $H^{\prime}-{ }^{\prime}$ lac $Z$ fusion was similar in the Plt-negative strains M18T, M18TI and M18TR (Fig. 7b), and was approximately $50 \%$ of that of the wildtype strain M18. Consistent with studies reporting that Plt could act as a signalling molecule (Brodhagen et al., 2004) to induce expression of $\mathrm{ABC}$ transport gene cluster (Brodhagen et al., 2005; Huang et al., 2006), we also found that the rhlQS system could directly regulate this Pltspecific $\mathrm{ABC}$ transporter alone, but did so in a Pltdependent manner. However, this must be distinct from the regulation of the QS system on pltR expression, because our evidence showed that expression of plt $R^{\prime}-{ }^{\prime}$ lac $Z$ fusion in Plt null mutant strains M18TI and M18TK was maintained at a high level (Fig. 7a).

Mutants defective in the $r h l \mathrm{QS}$ system survived longer than wild-type cells, suggesting retard cell death (Fig. 8a, b), which might confer a selective advantage on Pseudomonas sp. M18 in KMB broth. The mechanism behind this phenomenon may be related to a similar result that was recently discovered in a lasR mutant of $P$. aeruginosa (Heurlier et al., 2005). Whether the las system exists in strain M18 will need to be further investigated. The fact that the defective $r h l$ QS system led to enhanced cell viability, along with increased Plt production, may provide some hints for understanding the ecological roles of QS (Manefield \& Turner, 2002). However, the effect of a defective rhl QS system on root colonization and bio-control capacity should be investigated further.

In summary, we have presented preliminary results, and posited several suggestions, that may explain how the $r h l \mathrm{QS}$ system functions on several significant cell activities, including antibiotic biosynthesis, cell growth and pigment production. Future studies will determine the detailed mechanism of this RhlR-AHL complex on the regulation of these processes, and broaden the search for the putative regulators and pathways at work in strain M18.

\section{ACKNOWLEDGEMENTS}

This work was supported by the grants from the 10th Five-Year Programs of Chinese National Science (No.2004BA308A21-6) and the National Natural Science Foundation of China (No.30370041), and from the NCET in China. We are grateful to the referees and the editor for their helpful and valuable suggestions and revisions.

\section{REFERENCES}

Bailey, D. M., Johnson, R. E. \& Salvador, U. J. (1973). Pyrrole antibacterial agents. 1. Compounds related to pyoluteorin. J Med Chem 16, 1298-1300.

Bender, C., Rangaswamy, V. \& Loper, J. (1999). Polyketide production by plant-associated pseudomonads. Annu Rev Phytopathol 37, 175-196. 
Blumer, C., Heeb, S., Pessi, G. \& Haas, D. (1999). Global GacAsteered control of cyanide and exoprotease production in Pseudomonas fluorescens involves specific ribosome binding sites. Proc Natl Acad Sci U S A 96, 14073-14078.

Brint, J. M. \& Ohman, D. E. (1995). Synthesis of multiple exoproducts in Pseudomonas aeruginosa is under the control of RhlR-RhlI, another set of regulators in strain PAO1 with homology to the autoinducerresponsive LuxR-LuxI family. J Bacteriol 177, 7155-7163.

Brodhagen, M., Henkels, M. D. \& Loper, J. E. (2004). Positive autoregulation and signaling properties of pyoluteorin, an antibiotic produced by the biological control organism Pseudomonas fluorescens Pf-5. Appl Environ Microbiol 70, 1758-1766.

Brodhagen, M., Paulsen, I. \& Loper, J. E. (2005). Reciprocal regulation of pyoluteorin production with membrane transporter gene expression in Pseudomonas fluorescens Pf-5. Appl Environ Microbiol 71, 6900-6909.

Chen, C. C., Riadi, L., Suh, S. J., Ohman, D. E. \& Ju, L. K. (2005). Degradation and synthesis kinetics of quorum-sensing autoinducer in Pseudomonas aeruginosa cultivation. J Biotechnol 177, 1-10.

Chin-A-Woeng, T. F. C., van den Broek, D., de Voer, G., van der Drift, K. M. G. M., Tuinman, S., Thomas-Oates, J. E., Lugtenberg, B. J. J. \& Bloemberg, G. V. (2001). Phenazine-1-carboxamide production in the biocontrol strain Pseudomonas chlororaphis PCL1391 is regulated by multiple factors secreted into the growth medium. Mol Plant Microbe Interact 14, 969-979.

de Lorenzo, V., Cases, I., Herrero, M. \& Timmis, K. N. (1993). Early and late responses of TOL promoters to pathway inducers: identification of postexponential promoters in Pseudomonas putida with lacZ-tet bicistronic reporters. J Bacteriol 175, 6902-6907.

Dowling, D. N. \& O'Gara, F. (1994). Metabolites of Pseudomonas involved in the biocontrol of plant disease. Trends Biotechnol 12, 133-140.

El-Sayed, A., Hothersall, K. J. \& Thomas, C. M. (2001). Quorumsensing-dependent regulation of biosynthesis of the polyketide antibiotic mupirocin in Pseudomonas fluorescens NCIMB 10586 Microbiology 147, 2127-2139.

Fuqua, W. C., Parsek, M. R. \& Greenberg, E. P. (2001). Regulation of gene expression by cell-to-cell communication: acyl-homoserine lactone quorum sensing. Annu Rev Genet 35, 439-468.

Gambello, M. J. \& Iglewski, B. H. (1991). Cloning and characterization of the Pseudomonas aeruginosa lasR gene, a transcriptional activator of elastase expression. J Bacteriol 173, 3000-3009.

Ge, Y. H., Huang, X. O., Wang, S. L., Zhang, X. H. \& Xu, Y. Q. (2004). Phenazine-1-carboxylic acid is negatively regulated and pyoluteorin positively regulated by gacA in Pseudomonas sp. M18. FEMS Microbiol Lett 237, 41-47.

Haas, D. \& Keel, C. (2003). Regulation of antibiotic production in root-colonizing Peudomonas spp. and relevance for biological control of plant disease. Annu Rev Phytopathol 41, 117-153.

Heeb, S., Itoh, Y., Nishijyo, T., Schnider, U., Keel, C., Wade, J., Walsh, U., O'Gara, F. \& Haas, D. (2000). Small, stable shuttle vectors based on the minimal pVS1 replicon for use in Gram-negative, plant-associated bacteria. Mol Plant Microbe Interact 13, 232-237.

Heeb, S., Blumer, C. \& Haas, D. (2002). Regulatory RNA as mediator in GacA/RsmA-dependent global control of exoproduct formation in Pseudomonas fluorescens CHA0. J Bacteriol 184, 1046-1056.

Heurlier, K., Dénervaud, V., Haenni, M., Guy, L., Krishnapillai, V. \& Haas, D. (2005). Quorum-sensing-negative (lasR) mutants of Pseudomonas aeruginosa avoid cell lysis and death. J Bacteriol 187, 4875-4883.

Hoang, T. T., Karkhoff-Schweizer, R. R., Kutchma, A. J. \& Schweizer, H. P. (1998). A broad-host-range Flp-FRT recombination system for site-specific excision of chromosomally located DNA sequences: application for isolation of unmarked Pseudomonas aeruginosa mutants. Gene 212, 77-86.

Howell, C. R. \& Stipanovic, R. D. (1980). Suppression of Pythium ultimum-induced damping-off of cotton seedlings by Pseudomonas fluorescens Pf-5 and its antibiotic, pyoluteorin. Phytopathology 70, $712-715$.

Hu, H. B., Xu, Y. Q., Zhang, X. H. \& Hur, B. K. (2005). Isolation and characterization of a new fluorescent Pseudomonas strain that produces both phenazine 1-carboxylic acid and pyoluteorin. J Microbiol Biotechnol 15, 86-90.

Huang, X. Q., Zhu, D. H., Ge, Y. H., Zhang, X. H. \& Xu, Y. Q. (2004). Identification and characterization of pltZ, a gene involved in the repression of pyoluteorin biosynthesis in Pseudomonas sp. M18. FEMS Microbiol Lett 232, 197-202.

Huang, X. Q., Yan, A., Zhang, X. H. \& Xu, Y. Q. (2006). Identification and characterization of a putative $\mathrm{ABC}$ transporter PltHIJKN required for pyoluteorin production in Pseudomonas sp. M18. Gene 376, 68-78.

Jiang, Y., Camara, M., Chhabra, S. R., Hardie, K. R., Bycroft, B. W., Lazdunski, A., Salmond, G. P., Stewart, G. S. \& Williams, P. (1998). In vitro biosynthesis of the Pseudomonas aeruginosa quorum-sensing signal molecule N-butanoyl-L-homoserine lactone. Mol Microbiol 28, 193-203.

Keen, N. T., Tamaki, S., Kobayashi, D. \& Trollinger, D. (1988). Improved broad-host-range plasmids for DNA cloning in Gramnegative bacteria. Gene 70, 191-197.

Khan, S. R., Mavrodi, D. V., Jog, G. J., Suga, H., Thomashow, L. S. \& Farrand, S. K. (2005). Activation of the phz operon of Pseudomonas fluorescens 2-79 requires the LuxR homolog PhzR, N-(3-OHhexanoyl)-L-homoserine lactone produced by the LuxI homolog PhzI, and a cis-acting phz box. J Bacteriol 187, 6517-6527.

King, E. O., Ward, M. K. \& Raney, D. E. (1954). Two simple media for the demonstration of pyocyanin and fluorescein. J Lab Clin Med 44, 301-307.

Livak, K. J. \& Schmittgen, T. D. (2001). Analysis of relative gene expression data using real-time quantitative PCR and the $2^{-\Delta \Delta \mathrm{C}_{\mathrm{T}}}$ method. Methods 25, 402-408.

Manefield, M. \& Turner, S. L. (2002). Quorum sensing in context: out of molecular biology and into microbial ecology. Microbiology 148, 3762-3764.

Maurhofer, M., Keel, C., Schnider, U., Voisard, C., Haas, D. \& Defago, G. (1992). Influence of enhanced antibiotic production in Pseudomonas fluorescens strain CHA0 on its disease suppressive capacity. Phytopathology 82, 190-195.

Maurhofer, M., Reimann, C., Schimidli-Sachrer, P., Heeb, S., Haas, D. \& Défago, G. (1998). Salicylic acid biosynthesis genes expressed in Pseudomonas fluorescens strain P3 improve the induction of systemic resistance in tobacco against tobacco necrosis virus. Phytopathology 88, 678-684.

McClean, K. H., Winson, M. K., Fish, L., Taylor, A., Chhabra, S. R., Camara, M., Daykin, M., Lamb, J. H., Swift, S. \& other authors (1997). Quorum-sensing and Chromobacterium violaceum: exploitation of violacein production and inhibition for the detection of $\mathrm{N}$ acylhomoserine lactones. Microbiology 143, 3703-3711.

Medina, G., Juárez, K., Valderrama, B. \& Soberón-Chávez, G. (2003). Mechanism of Pseudomonas aeruginosa RhlR transcriptional regulation of the rhlAB promoter. J Bacteriol 185, 5976-5983.

Nowak-Thompson, B., Chaney, N., Wing, J. S., Gould, S. J. \& Loper, J. E. (1999). Characterization of the pyoluteorin biosynthetic gene cluster of Pseudomonas fluorescens Pf-5. J Bacteriol 181, 2166-2174. 
Ochsner, U. A. \& Reiser, J. (1995). Autoinducer-mediated regulation of rhamnolipid biosurfactant synthesis in Pseudomonas aeruginosa. Proc Natl Acad Sci U S A 92, 6424-6428.

Ochsner, U. A., Koch, A. K., Fiechter, A. \& Reiser, J. (1994). Isolation and characterization of a regulatory gene affecting rhamnolipid biosurfactant synthesis in Pseudomonas aeruginosa. J Bacteriol 176, 2044-2054.

Pearson, J. P., Gray, K. M., Passador, L., Tucker, K. D., Eberhard, A., Iglewski, B. H. \& Greenberg, E. P. (1994). Structure of the autoinducer required for expression of Pseudomonas aeruginosa virulence genes. Proc Natl Acad Sci U S A 91, 197-201.

Pearson, J. P., Passador, L., Iglewski, B. H. \& Greenberg, E. P. (1995). A second $N$-acylhomoserine lactone signal produced by Pseudomonas aeruginosa. Proc Natl Acad Sci U S A 92, 1490-1494.

Pesci, E. C., Pearson, J. P., Seed, P. C. \& Iglewski, B. H. (1997).

Regulation of las and $r h l$ quorum sensing in Pseudomonas aeruginosa. J Bacteriol 179, 3127-3132.

Reese, M. J. (2001). Application of time-delay neural network to promoter annotation in the Drosophila melanogaster genome. Comput Chem 26, 51-56.

Sambrook, J., Fritsch, E. F. \& Maniatis, T. (1989). Molecular Cloning: a Laboratory Manual, 2nd edn. Cold Spring Harbor, NY: Cold Spring Harbor Laboratory.

Savli, H., Karadenizli, A., Kolayli, F., Gundes, S., Ozbek, U. \& Vahaboglu, H. (2003). Expression stability of six housekeeping genes: a proposal for resistance gene quantification studies of Pseudomonas aeruginosa by real-time quantitative RT-PCR. J Med Microbiol 52, 403-408.

Schuster, M., Lostroh, C. P., Ogi, T. \& Greenberg, E. P. (2003). Identification, timing, and signal specificity of Pseudomonas aeruginosa quorum-controlled genes: a transcriptome analysis. J Bacteriol 185, 2066-2079.
Schweizer, H. D. (1993). Small broad-host-range gentamicin resistance gene cassettes for site-specific insertion and deletion mutagenesis. Biotechniques 15, 831-834.

Shaw, P. D., Ping, S. L., Daly, S. L., Cha, C., Cronan, J. E., Rinehart, K. L. \& Farrand, S. K. (1997). Detecting and characterizing $N$ acylhomoserine lactone signal molecules by thin-layer chromatography. Proc Natl Acad Sci U S A 94, 6036-6041.

Taga, M. E. \& Bassler, B. L. (2003). Chemical communication among bacteria. Proc Natl Acad Sci U S A 100, 14549-14554.

Thomashow, L. S. \& Weller, D. M. (1996). Current concepts in the use of introduced bacteria for biological disease control: mechanisms and antifungal metabolites. In Plant-Microbe Interactions, vol. 1, pp. 187236. Edited by G. Stacey \& N. T. Keen. New York: Chapman \& Hall.

Turner, J. M. \& Messenger, A. J. (1986). Occurrence, biochemistry and physiology of phenazine pigment production. Adv Microb Physiol 27, 211-275.

Waters, C. M. \& Bassler, B. L. (2005). Quorum sensing: cell to cell communication in bacteria. Annu Rev Cell Dev Bio 21, 319346.

Withers, H., Swift, S. \& Williams, P. (2001). Quorum sensing as an integral component of gene regulatory networks in gram-negative bacteria. Curr Opin Microbiol 4, 186-193.

Wood, D. W., Gong, F., Daykin, M. M., Williams, P. \& Pierson, L. S. (1997). N-acyl-homoserine lactone-mediated regulation of phenazine gene expression by Pseudomonas aureofaciens 30-84 in the wheat rhizosphere. J Bacteriol 179, 7663-7670.

Zhang, X. H., Wang, S. L., Gen, H. F., Hu, H. B. \& Xu, Y. Q. (2005). Differential regulation of $r s m A$ gene on biosynthesis of pyoluteorin and phenazine-1-carboxylic acid in Pseudomonas sp. M18. World J Microbiol Biotechnol 21, 883-889.

Edited by: J. Alfano 